\title{
Drilling Versus Imprinting for Establishing Crested Wheat- grass in the Sagebrush-Bunchgrass Steppe
}

\author{
M.R. HAFERKAMP, D.C. GANSKOPP, R.F. MILLER, AND F.A. SNEVA
}

\begin{abstract}
Effectiveness of a land imprinter and rangeland drill for establishing 'Nordan' crested wheatgrass (A gropyron desertorum) from fall plantings on loose and firm seedbeds was compared in the northern Great Basin in 1982 and 1984. Seedbed treatments applied on a Wyoming big sagebrush (A rtemisia tridentata subsp. wyomingensis)-Thurber needlegrass (Stipa thurberiana) habitat type included brushbeating, brushbeating plus disking, and no treatment. Crested wheatgrass seed was planted at $6.7 \mathrm{~kg} / \mathrm{ha}$ by broadcasting before imprinting broadcasting after imprinting, with a rangeland drill equipped with depth bands and at $3.4 \mathrm{~kg} / \mathrm{ha}$ with a rangeland drill with deep-furrow openers. Maximum seedling emergence occurred on brushbeat-disked seedbeds planted by $\cdot$ broadcasting before imprinting in $1982\left(37 / \mathrm{m}^{2}\right)$ and 1984 $\left(22 / \mathrm{m}^{2}\right)$ and by drilling with regular openers in $1982\left(23 / \mathrm{m}^{2}\right)$. Seedling emergence was almost twice as good with imprinting compared to drilling on loose-brushbeat-disked seedbeds, but 2 to 4 times more seedlings emerged from drilling than imprinting on firm-unprepared seedbeds. Maximum yields produced 2 and 3 years after planting averaged 500 to $1,000 \mathrm{~kg} / \mathrm{ha}$ on brushbeatdisked seedbeds planted by broadcasting before imprinting and regular drilling. Imprinting may be a viable alternative to drilling in this region on loose seedbeds.
\end{abstract}

Key Words: range improvements, range seeding, seedbed preparation

Drilling is considered the best method for planting seed on rangelands unless terrain or obstructions prevent its use (Vallentine et al. 1963, Vallentine 1980). Planting with a drill provides uniform distribution of seed and proper depth of planting on a firm

\footnotetext{
Authors are range scientist, USDA, Agricultural Research Service; range scientist, USDA, Agricultural Research Service; professor, Eastern Oregon Agricultural Research Center; and retired, USDA, Agricultural Research Service, Squaw Butte Station, Star Rt. 1, 4.51 Hwy. 205, Burns, Oregon.

Research was funded cooperatively by USDA, Agricultural Research Service Extramural Project No. 5090-201 13-004A(3) and Oregon State University, Agricultural Experiment Station. Published as Oregon Agricultural Experiment Station Technical Paper 8140.

Manuscript accepted 29 June 1987
}

seedbed. On loose soils, however, packing is usually required to achieve the degree of soil firmness needed for optimum control of planting depth, improved water holding capacity of the surface soil, enhanced capillary transfer of water to the seed, and optimum seed to soil contact (Hyder et al. 1955, Hyder and Sneva 1956, McGinnies 1962, Hyder and Bement 1969, Hyder and Bement 1970). Several rollers and planters have been developed to improve seedbeds on loose soils (Beutner and Anderson 1944, Hyder and Bement 1969, Hyder and Bement 1970, Marlatt and Hyder 1970, Vallentine 1980) including the Oregon Press Wheel drill designed by researchers located at Burns and Corvallis, Oregon (Hyder et al. 1961).

Broadcasting is generally employed where topography is too rough for drills to be used or where vast areas must be seeded, such as following large fires. Broadcast seeds are typically exposed to rapidly fluctuating moisture and temperature extremes and depredation by birds and rodents, thus they should be covered with soil (Nelson et al. 1970, Goebel 1978).

The land imprinter and the imprinting revegetation system appear to be effective for covering broadcast seed and for creating microdepressions to reduce runoff (Dixon and Simanton 1980, Anderson 1981). Results from imprinting have been variable in the southwestern United States, where much of the precipitation occurs as intense summer rains (Dixon 1983, Cox et al. 1986). Seedling emergence was improved by imprinting compared to drilling in Utah (Clary and Johnson 1983), and by imprinting compared to chaining after aerially broadcasting seed on a burned seedbed in southern Oregon (Ganskopp 1985). Measurements with a 30 degree cone-type penetrometer, in Oregon and Washington, have shown bottoms of depressions formed by an imprinter on disked seedbeds were more than twice as firm as ridges formed by an imprinter, bottoms of furrows formed by a rangeland drill, or adjacent unplanted disked soil (M.R. Haferkamp, file data, 1982 and 1986). In one study in eastern Washington, increased compaction resulting from fall imprinting was still evident 8 months later.

In the northern Great Basin, over half the precipitation falls as 
snow and spring rain, and most seedings are fall planted. Rangeland drills have traditionally been used for seeding. Except for the study conducted by Clary and Johnson (1983) in Utah, data comparing the effectiveness of the imprinter with the rangeland drill in the northwestern United States were lacking prior to 1982 . To fill this void of information, studies were initiated in 1982 to compare effectiveness of a land imprinter and rangeland drill for establishing 'Nordan' crested wheatgrass from fall plantings on loose and firm seedbeds in the northern Great Basin.

\section{Study Area and Methods}

The study was conducted on a Wyoming big sagebrush-Thurber needlegrass habitat type (Winward 1970, Hironaka 1979) located on the Squaw Butte Experiment Station, $68 \mathrm{~km}$ west of Burns, Ore. Elevation is $1,372 \mathrm{~m}$ and the sandy loam soil (Xerollic Durargids) is about $47 \mathrm{~cm}$ deep. The dominant shrubs, Wyoming big sagebrush and green rabbitbrush (Chrysothamnus viscidiflorus subsp. viscidiflorus), provide about $15 \%$ canopy cover (Doescher et al. 1984). Dominant grasses, bottlebrush squirreltail (Sitanion hystrix), Sandberg bluegrass (Poa sandbergii), and Thurber needlegrass, provide $21.3 \%$ basal cover. Peak standing herbage production was $627 \mathrm{~kg} / \mathrm{ha}$ in 1982, a wet year. Mean annual precipitation is $29 \mathrm{~cm}$ with peak accumulations occurring in the October to June period.

Seedbed treatments included control (unprepared), brushbeating with a rotobeater (Vallentine 1980), and brushbeating plus disking. The unprepared seedbed was firm with live herbaceous plants and shrubs. Brushbeating killed most sagebrush plants, removed tops but did not kill green rabbitbrush plants, and left a firm seedbed with undamaged herbaceous plants. Brushbeating plus disking killed most shrubs and herbaceous plants and provided a loose seedbed. Plot preparation in 1982 and 1984 included brushbeating and disking in August to destroy established plants, redisking in September after fall rains to destroy seedlings, and planting in October. Preparation by disking in 1984 followed a similar schedule but utilized plots that had been brushbeat in 1982 .

Nordan crested wheatgrass seed was planted at $6.7 \mathrm{~kg}$ pure live seed (PLS)/ ha by broadcasting before imprinting, broadcasting after imprinting, and with a rangeland drill (Young and McKenzie 1982) equipped with single-disked openers with $2.5-\mathrm{cm}$ depth bands, and at $3.4 \mathrm{~kg}$ PLS/ha with a rangeland drill equipped with deep-furrow openers (Asher and Eckert 1973). The land imprinter consists of an interior tank measuring $1 \mathrm{~m}$ (diameter) and $2 \mathrm{~m}$ (length) and a set of wedge shape teeth measuring 1.2 by 15 by 15 $\mathrm{cm}$ welded to its outside circumference. The angles produce a pattern that is $10-\mathrm{cm}$ deep when full penetration is attained. Waterfilled weight is about $4.1 \mathrm{Mg}$.

Four replications were arranged in a strip-plot design with years as major plots, seedbed preparation as subplots, and planting method as sub-subplots. Individual sub-subplots were 15 by $30 \mathrm{~m}$ in size. Plots were prepared and planted in 1982 and 1984.

Density and frequency of crested wheatgrass seedlings or plants in the 1982 planting were determined in ten 30 by $60-\mathrm{cm}$ quadrats in each treatment in September 1983, August 1984, and July 1984 and 1986. Heights of at least 10 plants per treatment were measured to the nearest centimeter in 1983. Standing crops of crested wheatgrass were harvested by clipping to ground level in ten 30 by $60-\mathrm{cm}$ quadrats in 1985 and 1986, and standing crops of other herbaceous plants were sampled in 1986. Samples were oven-dried at $60^{\circ} \mathrm{C}$ for 48 hours. Basal cover of grasses and canopy cover of shrubs were determined in 1985 by line intercept using a 30-m tape positioned diagonally across each 15 by $30-\mathrm{m}$ plot planted by drilling or broadcasting before imprinting.

The 1984 planting was evaluated by measuring density and frequency of crested wheatgrass in July 1985 and July 1986 and standing crops of crested wheatgrass and other herbaceous plants in 1986. In July 1985 heights of crested wheatgrass plants were measured, and canopy cover of shrubs and basal cover of other grasses were determined by line intercept.

Soil water content was measured gravimetrically on 4 samples collected from each seedbed preparation in areas planted by drilling and imprinting. Soil samples were collected from the 0 to $5-\mathrm{cm}$ depth at planting in the 1982 and 1984 plantings and from early April to mid-July 1985 from the 0 to $5-\mathrm{cm}$ and 5 to $30-\mathrm{cm}$ depths in the 1984 planting. Soil samples were collected from the bottoms of furrows or imprint depressions, areas usually having the greatest seedling densities.

Soil were dry at planting with water contents averaging 8.2, 9.9, and $8.1 \%$ in 1982 and $4.8,4.2$, and $6.2 \%$ in 1984 on unprepared, brushbeat, and brushbeat-disked seedbeds, respectively. Soil water content at $-1.5 \mathrm{MPa}$ averaged $9 \%$. Penetrometer measurements to compare soil compaction were not collected during this study.

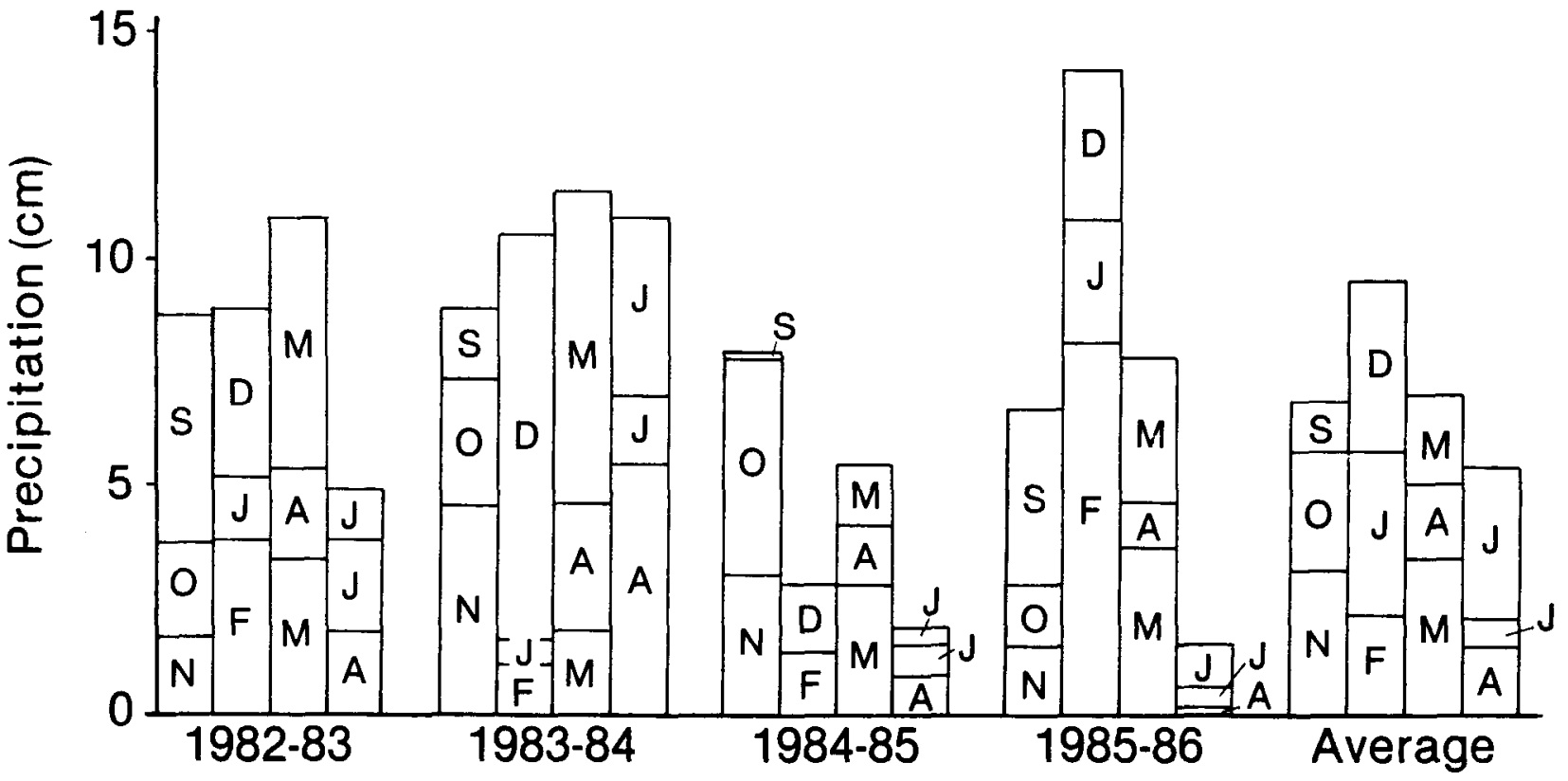

Fig. 1. Seasonal precipitation at the Squaw Butte Experimental Range. 
Analysis of variance was used to test the effect of years, methods of seedbed preparation, methods of planting and interactions. Mean separation tests were made using $\mathrm{LSD}_{0.06}$ using standard errors calculated by techniques described by Petersen (1985) for the stripplot design.

\section{Results}

Fall precipitation was similar for the 2 planting years, but precipitation in winter, spring, and summer was greater in 1982-83 than in 1984-85 (Fig. 1). During the drier 1985, soil water content in the 0 to $5-\mathrm{cm}$ depth declined from $12 \%$ in early April to $4 \%$ in late May, and soil water content in the 5 to $30-\mathrm{cm}$ zone decreased from $19 \%$ in early April to $5 \%$ in early July. Soil water contents of samples collected in the bottom of drill rows and imprint depressions were not significantly different regardless of seedbed preparation method. Total precipitation, the second year following planting, was greatest for the 1982 planting. Seasonally the 1983-84 year was wetter than the 1985-86 year with the exception of the winter period.

Figure 2 is a summary of seedling emergence for the 2 planting years, 3 seedbed preparation methods, and 4 planting techniques. Significant two-way interactions, however, suggest seedling emergence resulting from the 4 planting methods varies with year of planting and seedbed preparation method (Table 1). More than twice as many seedlings emerged from drilling with regular openers in 1982 compared to 1984 , while densities were similar between years for the other planting methods (Table 1). Maximum densities of seedlings emerged the first summer on plots planted by drilling with regular openers in 1982 and broadcasting seed before imprinting in 1982 and 1984 (Table 1). Significantly ( $p \leq 0.05$ ) more seedlings emerged on the brushbeat-disked compared to unprepared and brushbeat seedbeds planted by drilling with regular openers
Table 1. Crested whentgrass seedling dencity (seedlings/m²) the first summer after planting for the 1982 and 1984 planting seasons and seedbed preparation method by planting method.

\begin{tabular}{|c|c|c|c|c|}
\hline & \multicolumn{4}{|c|}{ Planting method } \\
\hline & $\begin{array}{l}\text { Regular } \\
\text { drill }\end{array}$ & $\begin{array}{l}\text { Deep-furrow } \\
\text { drill }\end{array}$ & $\begin{array}{l}\text { Seed } \\
\text { imprint }\end{array}$ & $\begin{array}{l}\text { Imprint } \\
\text { seed }\end{array}$ \\
\hline Year & \multicolumn{4}{|c|}{- seedlings $/ \mathrm{m}^{2}$} \\
\hline 1982 & 15 & 3 & 15 & 4 \\
\hline 1984 & 6 & 2 & 9 & 4 \\
\hline \multicolumn{5}{|l|}{ Seedbed } \\
\hline Unprepared & 7 & 3 & 3 & 2 \\
\hline Brushbeat & 8 & 5 & 3 & 1 \\
\hline Brushbeat-disk & 16 & 1 & 30 & 10 \\
\hline
\end{tabular}

$\mathrm{LSD}_{0.05}=7$, between years with same planting method.

$\mathrm{LSD}_{0.0}=6$, between planting methods within same year.

$\operatorname{LSD}_{0.06}=7$, between seed beds with same planting method.

ISD $0.08=6$, between planting methods on same seedbed.

and broadcasting seed before or after imprinting. On the unprepared and brushbeat seedbeds, seedlings were more dense when seeds were planted by drilling with regular openers, but emergence per meter of row was similar, $10 / \mathrm{m}$, for the 2 drilling treatments, since drilling with regular openers planted twice as many rows per plot as deep-furrow drilling. Differences between drilling and other planting methods were not always statistically significant (Table 1). Broadcasting seed before imprinting increased seedling emergence 2 and 3 fold over drilling with regular openers and broadcasting seed after imprinting on the brushbeat-disked seedbed.

Plant densities decreased the second summer of both plantings

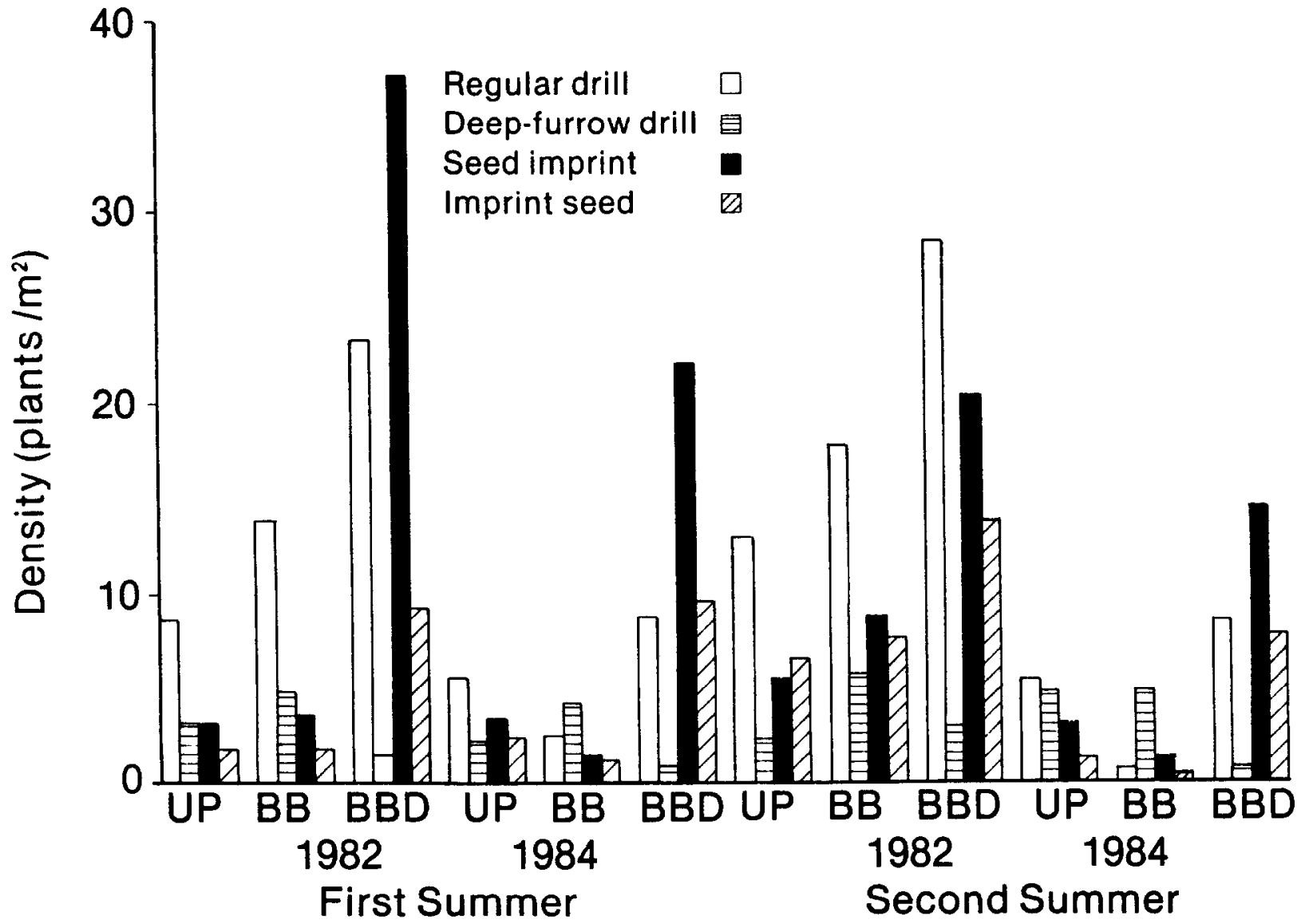

Fig. 2. Crested wheatgrass seedling and plant densities the first and second summer after planting on unprepared (UP), brushbeat (BB), and brushbeat-disked (BBD) seedbeds on experimental plots at the Squaw Butte Experimental Range. 
on brushbeat-disked seedbeds planted by broadcasting and imprinting (Fig. 2). Seedling numbers were greatest on these plots the first summer. In the 1982 seeding, plant densities on most seedbeds increased slightly the second summer with the remaining planting methods, while densities in the 1984 planting remained constant. Analysis of the significant two-way interactions show that although plants were usually more dense the second summer on plots planted in 1982 the differences was significant only on plots planted by drilling with regular openers (Tables 2 and 3). Averaged

Table 2. Crested wheatgrass plant density (plants $/ \mathrm{m}^{2}$ ) the second summer after planting for the 1982 and 1984 planting seasons by seedbed preparation method. Plots were planted by regular drilling, deep-furrow drilling, broadcasting seed before imprinting, or broadcasting seed after imprinting.

\begin{tabular}{lccc}
\hline \hline & \multicolumn{3}{c}{ Seedbed preparation method } \\
\cline { 2 - 4 } Planting year & Unprepared & Brushbeat & Brushbeat-disk \\
\hline & & plants $/ \mathrm{m}^{2}$ & \\
1982 & 7 & 10 & 17 \\
1984 & 4 & 2 & 8 \\
\hline
\end{tabular}

I $\mathrm{SD}_{0.08}=12$, between years on same seedbed.

$\mathrm{LSD}_{0.06}=7$, between seedbeds within same year.

across years, significantly more plants were established by drilling with regular openers on the brushbeat-disked compared to the unprepared and brushbeat seedbeds. As with seedling densities, plant densities were greatest when seeds were planted by drilling with regular openers on the unprepared and brushbeat seedbeds. In contrast to the first summer, plant densities were similar on brushbeat-disked seedbeds planted by broadcasting seed before

Table 3. Crested wheatgrass plant density (plant/ $\mathrm{m}^{2}$ ) the second summer after planting for the 1982 and 1984 planting seasons and seedbed preparation method by planting method.

\begin{tabular}{|c|c|c|c|c|}
\hline & \multicolumn{4}{|c|}{ Planting method } \\
\hline & $\begin{array}{c}\text { Regular } \\
\text { drill }\end{array}$ & $\begin{array}{c}\text { Deep-furrow } \\
\text { drill }\end{array}$ & $\begin{array}{c}\text { Seed } \\
\text { imprint }\end{array}$ & $\begin{array}{l}\text { Imprint } \\
\text { seed }\end{array}$ \\
\hline Year & & plant & $\mathrm{m}^{2}$ & \\
\hline 1982 & 20 & 4 & 12 & 9 \\
\hline 1984 & 5 & 4 & 6 & 3 \\
\hline Seedbed & & - plant & $\mathrm{m}^{2}$ & \\
\hline Unprepared & 9 & 4 & 4 & 4 \\
\hline Brushbeat & 9 & 5 & 5 & 4 \\
\hline Brushbeat disk & 19 & 2 & 18 & 11 \\
\hline
\end{tabular}

LSD $0.06=10$, between years with same planting method.

$\operatorname{LSD}_{0.06}=6$, between planting methods within same year.

$\operatorname{LSD}_{0.06}=5$, between seedbeds with same planting method.

$\operatorname{LSD}_{0.06}=6$, between planting methods on same seedbed.

imprinting and drilling with regular openers. Significantly more plants were established by these 2 techniques than by broadcasting after imprinting or deep-furrow drilling.

Seedlings were most evenly distributed on seedbeds prepared by brushbeating and disking and planted by regular drilling and broadcasting with imprinting (Table 4). Seedling distribution was intermediate on unprepared or brushbeat seedbeds planted by drilling. Poorest seedling distribution occurred on unprepared and brushbeat seedbeds planted by imprinting and brushbeat-disked seedbeds planted by deep-furrow drilling. Plant distribution the second summer was similar to seedling distribution the first summer. In general, plants were more evenly distributed in the 1982 seeding than the 1984 seeding.

Basal cover of native grasses and canopy cover of shrubs were determined $I$ and 3 years after planting the 1984 and 1982 seedings, respectively. Basal cover of native grasses was significantly reduced
Table 4. Crested wheatgrass seedling frequency $(\%)$ the first summer after planting for the 1982 and 1984 planting seasons and seedbed preparation method by planting method.

\begin{tabular}{lcccc}
\hline & \multicolumn{4}{c}{ Planting method } \\
\cline { 2 - 5 } & $\begin{array}{c}\text { Regular } \\
\text { drill }\end{array}$ & $\begin{array}{c}\text { Deep-furrow } \\
\text { drill }\end{array}$ & $\begin{array}{c}\text { Seed } \\
\text { imprint }\end{array}$ & $\begin{array}{c}\text { Imprint } \\
\text { seed }\end{array}$ \\
\hline Year & - & & & \\
1982 & 74 & 40 & 57 & 43 \\
1984 & 52 & 42 & 46 & 43 \\
Seedbed & & & & \\
Unprepared & 50 & 45 & 36 & 28 \\
Brushbeat & 51 & 53 & 26 & 79 \\
Brushbeat-disk & 88 & 25 & 91 & 21 \\
\hline
\end{tabular}

$\mathrm{LSD}_{0.06}=34$, between years with same planting method.

$\mathrm{LSD}_{0.06}=24$, between planting methods within same year.

LSD $D_{\mathrm{m}}=33$, between seedbeds with same planting method.

$\mathrm{LSD}_{0.05}=32$, between planting methods on same seedbed.

to less than $1 \%$ by brushbeating and disking (Table 5). On unprepared and brushbeat seedbeds Thurber needlegrass averaged 1.5 and $1.5 \%$, Sandberg bluegrass 1.2 and $0.5 \%$, and bottlebrush squirreltail 0.8 and $0.5 \%$ in the 1984 and 1982 seedings, respectively.

Table 5. Basal cover $(\%)$ of aseociated perennial grasses growing on seeded plots in 1985 for the 1982 and 1984 planting year by seedbed preparation method.

\begin{tabular}{|c|c|c|c|}
\hline \multirow[b]{2}{*}{ Planting year } & \multicolumn{3}{|c|}{ Seedbed preparation method } \\
\hline & Unprepared & Brushbeat & Brushbeat-disk \\
\hline & & $-\%$ & \\
\hline \multirow[t]{2}{*}{1982} & 2.5 & 2.9 & 0.4 \\
\hline & & $\mathrm{LSD}_{0.06}=1.3$ & \\
\hline \multirow[t]{2}{*}{1984} & 3.6 & 4.0 & 0.0 \\
\hline & & $\operatorname{LSD}_{0.06}=0.6$ & \\
\hline
\end{tabular}

Shrub canopy cover was significantly reduced by brushbeating and reduced slightly more by disking in the 1984 seeding (Table 6). A similar trend held 3 years after preparing the 1982 seedbeds (Table 6). Differences in canopy cover between drilling and imprinting were significant for the 1984, but not the 1982 seeding. Imprinting reduced total shrub canopy cover in the 1984 seeding

Table 6. Canopy cover (\%) of shrubs growing on seeded plots in 1985 for the 1982 and 1984 planting year by planting method and seedbed preparation method.

\begin{tabular}{|c|c|c|c|c|}
\hline \multirow[b]{2}{*}{$\begin{array}{l}\text { Planting } \\
\text { year }\end{array}$} & \multirow[b]{2}{*}{$\begin{array}{l}\text { Planting } \\
\text { method }\end{array}$} & \multicolumn{3}{|c|}{ Seedbed preparation method } \\
\hline & & Unprepared & Brushbeat & $\begin{array}{l}\text { Brushbeat- } \\
\text { disk }\end{array}$ \\
\hline 1982 & Average & 13 & $\begin{array}{c}8 \\
\mathrm{LSD}_{0.06}=6\end{array}$ & 2 \\
\hline 1984 & $\underset{\text { Imprint }}{\text { Drill }}$ & $\begin{array}{r}12 \\
8\end{array}$ & $\begin{array}{l}4 \\
2\end{array}$ & $\begin{array}{l}0 \\
1\end{array}$ \\
\hline
\end{tabular}

$\operatorname{LSD}_{0.00}=4$, between planting methods on same seedbed.

$\mathrm{LSD}_{0.00}=3$, between seedbeds with same planting method.

$4 \%$ more than drilling, but $8 \%$ canopy cover remained after imprinting. Canopy cover of Wyoming big sagebrush decreased from $8.8 \%$ with drilling to $2.5 \%$ with imprinting on unprepared seedbeds, while cover of green rabbitbrush increased from $2.9 \%$ 


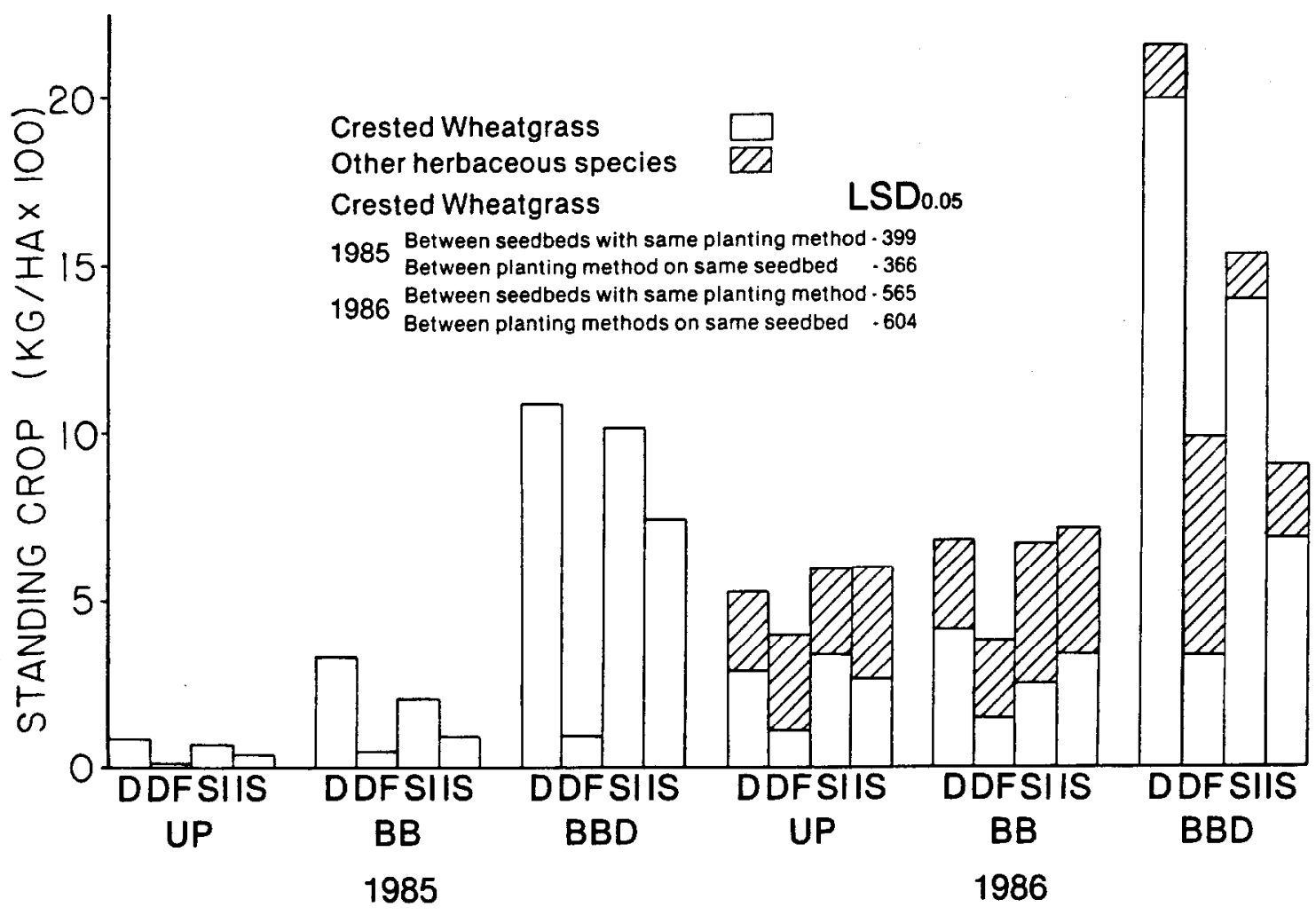

Fig. 3. The 1985 and 1986 standing crops of crested wheatgrass and other herbaceous species growing in plots planted in 1982 by drilling ( $D$ ), deep-furrow drilling (DF), broadcasting before imprinting (SI), and broadcasting after imprinting (IS) on unprepared (UP), brushbeat (BB), and brushbeat-disked $(B B D)$ seedbeds at the Squaw Butte Experimental Range.

with drilling to $5.7 \%$ with imprinting. Green rabbitbrush was also the dominant shrub on brushbeat and brushbeat-disked seedbeds. Similar trends were observed in the 1982 seeding except canopy cover of Wyoming big sagebrush on unprepared seedbeds was $8.5 \%, 3$ years after planting.

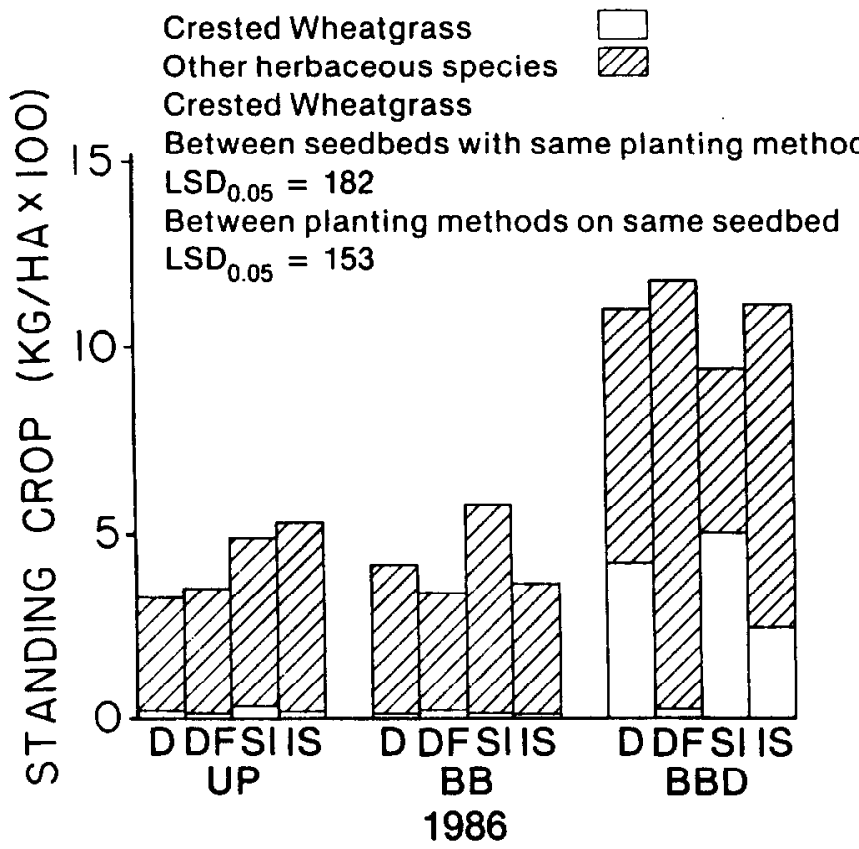

Fig. 4. The 1986 standing crops of crested wheatgrass and other herbaceous species growing in plots planted in 1984 by drilling (D), deep-furrow drilling ( $D F$ ), broadcasting before imprinting (SI), and broadcasting after imprinting (IS) on unprepared (UP), brushbeat (BB), and brushbeatdisked (BBD) seedbeds at the Squaw Butte Experimental Range.
Presence of indigenous vegetation on unprepared and brushbeat seedbeds and the reduced amount of precipitation in 1985 affected growth of crested wheatgrass seedlings the first summer after planting. In 1983, seedlings growing on the brushbeat-disked seedbeds were $35-\mathrm{cm}$ tall, a significant $(p \leq 0.05) 22 \mathrm{~cm}$ taller than seedlings growing on the unprepared and brushbeat seedbeds. Results were similar in 1985 , but due to dry conditions few seedlings were found growing on the unprepared seedbeds, thus, this treatment was not sampled. Seedling heights on brushbeat and brushbeat-disked seedbeds averaged $24 \mathrm{~cm}$ in 1983 compared to $17 \mathrm{~cm}$ in the drier 1985 . Heights were not significantly $(p \leq 0.05)$ different either year for seedlings established by drilling compared to imprinting.

Crested wheatgrass yields 3 and 4 years after planting on the 1982 seeding ranged from 11 to almost $2,000 \mathrm{~kg} / \mathrm{ha}$ (Fig. 3). Drilling with regular openers and broadcasting before imprinting on brushbeat-disked seedbeds produced yields greater than 1,000 $\mathrm{kg} / \mathrm{ha}$ both years, and broadcasting after imprinting on disked seedbeds yielded over $500 \mathrm{~kg} / \mathrm{ha}$. Drilling with regular openers, broadcasting before imprinting, and broadcasting after imprinting on disked seedbeds also produced maximum crested wheatgrass yields the second summer after planting the 1984 seeding (Fig. 4). Yields in 1986 of the other herbaceous species, growing on unprepared, brushbeat, and brushbeat-disked seedbeds averaged 288 , 350 , and $309 \mathrm{~kg}$ / ha, respectively, in the 1982 seeding and 398, 409, and $783 \mathrm{~kg} / \mathrm{ha}$ in the 1984 seeding. Samples from unprepared and brushbeat seedbeds consisted primarily of perennial grasses, while samples from disked seedbeds consisted of mainly annual grasses and forbs. The increase in total herbaceous yield observed on the disked compared to other seedbeds may have occurred because of increased nitrogen resulting from incorporation of organic matter with the disking process, change in plant species occupying the site, and/or omission of the shrub component from the total yield on unprepared and brushbeat seedbeds. 


\section{Discussion}

Results of this study show dense stands of crested wheatgrass seedlings and plants can be established in the sagebrush-bunchgrass steppe by fall drilling with regular openers on loose and firm seedbeds, by deep-furrow drilling on firm seedbeds, and fall broadcasting and imprinting on loose seedbeds. The land imprinter was initially developed to enhance establishment of seedlings in the arid Southwest. In that environment retention of water, from intense summer rains, is critical to provide adequate moisture for seed germination and seedling establishment. In contrast, the precipitation pattern in the northern Great Basin, mainly rain or snow in the fall, winter, or spring, often provides adequate moisture for germination of fall-planted seed and seedling emergence as snow melt occurs in the spring. The similar soil water content measured on the 3 seedbeds planted by drilling and imprinting imply that differences in seedling establishment were due to factors other than improved soil water retention. Subtle variations in surface soil water contents, not detected by our methods, may provide a plausible explanation.

We hypothesize the increase in seedling density with imprinting resulted from packing loose soil, improving seed-to-soil contact, and planting more crested wheatgrass seeds at the proper depth. This hypothesis is supported by emergence of fewer seedlings on plots planted by drilling with regular openers and broadcasting seed after imprinting. In addition, we observed more seedling emergence from the ridges formed by the imprinter when seed was broadcast before imprinting than when seed was broadcast on imprinted seedbeds. Seed burial with a rangeland drill ranges from the soil surface to the maximum depth allowed by depth bands. The depth bands may be less effective in controlling depth on extremely loose seedbeds or when drills are pulled so fast that soil is thrown by openers into adjacent furrows. Seed broadcast after imprinting is buried at varying depths with some seed lying on the soil surface, some falling into cracks, and some covered by natural sloughing. The poor emergence with the deep-furrow drill on disked seedbeds probably resulted when seed was buried too deeply by loose soil thrown into furrows by openers and by natural sloughing. In this study seeding rates were equal between regular drilling and imprinting, about 200 pure live seeds $/ \mathrm{m}^{2}$. Thus, reducing seeding rates when broadcasting and then imprinting may be possible, especially when seed costs are high.

Poorer seedling emergence was attained with imprinting compared to drilling on relatively firm seedbeds resulting from no preparation and brushbeating. These differences were more obvious in the wetter period, 1982-83. In these conditions, the imprinter was not heavy enough to penetrate into the soil and form complete imprints and ridges. Thus, the major effects of the imprinter, soil compaction and seed burial, were lost. Additional weight added to the imprinter on these seedbeds may be beneficial, but effects of increased weight were not addressed in this study.

The requirement for reduction of indigenous plants for successful establishment of crested wheatgrass stands was obvious. Whether the reduction resulted from furrow openers or disking, the initial result was increased seedling density. Denser stands of seedlings developed rapidly and produced productive stands of crested wheatgrass plants within 3 years. Imprinting has been proposed as a method of brush control. In this study imprinting reduced canopy cover of shrubs more than drilling 9 months after treatment, but the difference was not apparent after 30 months. The greatest decrease resulted from breakage of stems of mature Wyoming big sagebrush plants. Green rabbitbrush plants and younger sagebrush plants with limber stems, however, were unaffected.

Land imprinting enhanced seedling establishment in this study, but on rock-free-loose seedbeds other implements designed to pack the soil may have provided similar results (Beutner and Anderson
944, Hyder et al. 1961, Hyder and Bement 1969, Hyder and Bement 1970, Marlatt and Hyder 1970, Vallentine 1980). The land imprinter, a rugged piece of equipment, works well on rangeland. It provides good seed burial, good seed-to-soil contact, and moisture retaining microdepressions that can effectively shield developing seedlings from wind. The imprinter is narrower than the rangeland drill, and fewer hectares can be seeded in a given period of time compared to drilling. Some estimate imprinting costs about 33\% more than drilling (Clary and Wagstaff 1987). Imprinting may, however, be a viable alternative to drilling where soils are so loose seeding depth cannot be controlled with depth bands, extremely dense stands of seedlings are needed to compete with noxious plants, rows are undesirable for aesthetic reasons, or seed costs are high.

\section{Literature Cited}

Anderson, R. 1981. A story in two parts, advance of the barren earth, technology for reversing desertification. Rangelands 3:47-50.

Asher, J.E., and R.E. Eckert, Jr. 1973. Development, testing, and evaluation of the deep furrow drill arm assembly for the rangeland drill. $J$. Range Manage. 26:377-379.

Beutner, E.L., and D. Anderson. 1944. Notes-A method of seedbed preparation and reseeding deteriorated rangelands. J. Amer. Soc. Agron. 36:171-172.

Clary, W.C., and T.J. Johnson. 1983. Land imprinter results in Utah, p. 23-24. In: 37th Annu. Rep., Vegetative Rehabilitation \& Equipment Workshop. 13-14 February 1983. Albuquerque, N.M. USDA Forest Serv., Equipment Development Center, Missoula, Mon.

Clary, W.C., and F.J. Wagstaff. 1987. Biological and economic effectiveness of several revegetation techniques in the pinyon-juniper-sagebrush zone, p. 305-312. In: Everett, R.L. (compiler) Proc.-Pinyon-Juniper Conf. 13-16 January 1986, Reno, Nev. USDA Forest Serv., Intermountain Res. Stat.. Gen. Tech. Rep. Int-215.

Dixon, R.M. 1983. Land imprinting activities, p. 13. In: 37th Annu. Rep., Vegetative Rehabilitation \& Equipment Workshop. 13-14 February 1983, Albuquerque, N.M. USDA Forest Serv., Equipment Development Center, Missoula, Mon.

Dixon, R.M., and J.R. Simanton. 1980. Land imprinting for better watershed management, p. 809-826. In: Symp. on Watershed Manage. Vol. II. 21-23 July 1980. Boise, Ida. Amer. Soc. Civil Eng.

Doescher, P.S., R.F. Miller, and A.H. Winward. 1984. Soil chemical patterns under eastern Oregon plant communities dominated by big sagebrush. Soil Sci. Soc. Amer. J. 48:659-663.

Ganskopp, D.C. 1985. Success of broadcast seeding on untreated, imprinted and chained rangelands, p. 4-6. In: 1985 Prog. Rep....Res. in Range. Manage. Oregon Agr. Exp. Sta. Spec. Rep. 743.

Goebel, C.J. 1978. Grass establishment on lower snake river rangelands. p. 629-630. In: D.N. Hyder (ed.) Proc. First Internat. Rangeland Congr. 14-18 Aug. 1978, Denver, Colo. Soc. for Range Manage., Denver, Colo.

Hironaka, M. 1979. Basic synecological relationships of the Columbia River sagebrush type. p. 27-32. In: The sagebrush ecosystem-a symposium. April 1978. Utah State Univ., Logan, Utah.

Hyder, D.N., and R.E. Bement. 1969. A micro-ridge roller for seedbed modification. J. Range Manage. 22:54-56.

Hyder, D.N., and R.E. Bement. 1970. Soil physical conditions after plowing and packing of ridges. J. Range Manage. 23:289-292.

Hyder, D.N., D.E. Booster, F.A. Sneva, W.A. Sawyer, and J.B. Rodgers. 1961. Wheel-track planting on sagebrush-bunchgrass range. J. Range Manage. 14:220-224.

Hyder, D.N., and F.A. Sneva. 1956. Seed and plant-soil relations as affected by seedbed firmness on a sandy loam rangeland soil. Soil Sci. Soc. Amer. Proc. 20:416-419.

Hyder, D.N., F.A. Sneva, and W.A. Sawyer. 1955. Soil firming may improve range seeding operations. J. Range Manage. 8:159-163.

Marlatt, W.E.,, and D.N. Hyder. 1970. Soil ridging for reduction of wind erosion from grass seedbeds. J. Range Manage. 23:170-174.

McGinnies, W.J. 1962. Effect of seedbed firming on the establishment of crested wheatgrass seedlings. J. Range Manage. 15:230-234.

Nelson, J.R., A.M. Wilson, and C.J. Goebel. 1970. Factors influencing broadcast seeding in bunchgrass range. J. Range Manage. 23:163-170.

Petersen, R.G. 1985. Design and analysis of experiments. (Stat. textbooks and monogr.; v. 66). Marcel Dekker, Inc. New York, New York. 
Vallentine, J.F. 1980. Range development and improvements. Second edition. Brigham Young Univ. Press, Provo, Utah.

Vallentine, J.F., C.W. Clark, and L.A. Stoddart. 1963. Range seeding in Utah. Utah Ext. Ser. Circ. 307.
Winward, A.H. 1970. Taxonomic and ecological relationships of the big sagebrush complex in Idaho. Ph.D. Diss. Univ. of Idaho, Moscow. Univ. Microfilms, Ann Arbor, Mich. (Diss. Abstr. 31(B):3791 B-3792B). Young, J.A., and D. MeKenzie. 1982. Rangeland drill. Rangelands 